
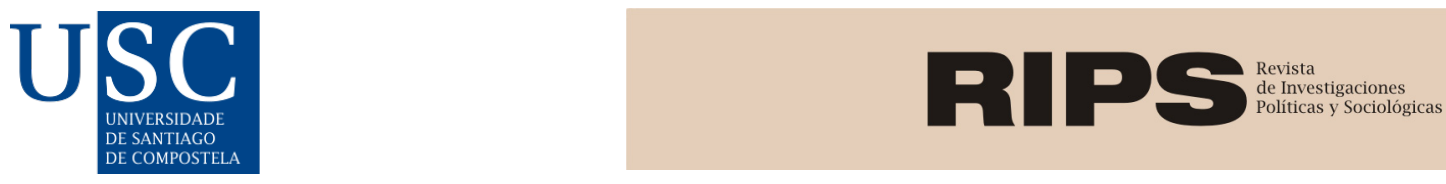

RIPS: Revista de Investigaciones Políticas y Sociológicas, 20(1), 2021. ISSN: 2255-5986

https://doi.org/10.15304/rips.20.1.7719

Artículos

\title{
Brexit and the Irish Border
}

El Brexit y la frontera irlandesa

\author{
Michael Keating ${ }^{1}$ \\ ${ }^{1}$ University of Aberdeen
}

Recibido: 18/05/2021; Aceptado: 19/05/2021

\begin{abstract}
The Irish border proved one of the most difficult issues in the negotiations on the United Kingdom's withdrawal from the European Union. A persistent point of contention since the partition of Ireland a hundred years ago, it had been put into abeyance by a combination of the historic Common Travel Area, the peace settlement in Northern Ireland and the EU Single Market, which had allowed the disappearance of physical structures. The final agreement leaves important areas of ambiguity but does represent a breach in the UK's vision of Brexit and a single settlement for the whole of the United Kingdom. It represents the first time that the EU has permitted partial integration in the EU for a region of a non-Member State but the circumstances are such that it does not provide a precedent.
\end{abstract}

Keywords: Brexit; Ireland; Irish border; United Kingdom; European Union

\section{Resumen}

La frontera irlandesa resultó ser uno de los temas más difíciles en las negociaciones sobre la retirada del Reino Unido de la Unión Europea. Un punto de discordia persistente desde la separación de Irlanda hace cien años, había quedado en suspenso por una combinación de la histórica Common Travel Area, el acuerdo de paz en Irlanda del Norte y el mercado único de la UE, que había permitido la desaparición de las estructuras físicas. El acuerdo final deja importantes áreas de ambigüedad, pero representa una brecha en la visión británica del Brexit y un acuerdo único para todo el Reino Unido. Representa la primera vez que la UE permite la integración parcial en la UE de una región de un Estado no miembro, pero las circunstancias son tales que no sienta un precedente.

Palabras clave: Brexit; Irlanda; frontera irlandesa; Reino Unido; Unión Europea

\section{History of the Border}

The history of the Irish border question goes back to the 1921 partition of Ireland following the military and political conflict over Irish independence. An Irish Free State was established in 26 counties of the southern part of the island. Six counties in the north-east remained in 
the United Kingdom as the autonomous province of Northern Ireland. This represented a very imperfect separation of the nationalist (largely Catholic) and unionist (predominantly Protestant) communities. Catholics made up around a third of the population of Northern Ireland and a majority in two of the six counties. Northern Ireland in practice remained the largest area that unionists could carve out and still retain a majority. Protestants had comprised 10.4 per cent of the population of the 26 counties in 1911, although their numbers had dwindled to four per cent by the 1970s (Todd 2018) as a result of migration to the North, to Great Britain or overseas.

Under the Anglo-Irish Treaty, the Irish Free State was formally a self-governing Dominion under the Crown with the same status as Canada. The fact that it was not a Republic sparked a civil war in the south, won by the pro-Treaty side. In practice, successive governments sought to make it look as much like sovereign independence as possible. The Statute of Westminster (1931) recognized the effective independence of the dominions and in 1937 Ireland gave itself a new constitution, downgrading the monarchy. Finally, in 1949, it established the Republic of Ireland and left the Commonwealth. The response of the UK Government was to extend a guarantee to Northern Ireland that it would not be incorporated in the Republic without the consent of its Parliament. The Republic of Ireland would not be regarded as a foreign country and Irish citizens would be treated still as though they were British subjects although, not being citizens they would have no automatic right to British passports. They could vote in UK elections when resident in Great Britain; only if resident in Northern Ireland, they could vote in Northern Ireland elections. Subsequent codifications of British citizenship as a separate category from subjects, including restrictions on immigration, left this Irish exception untouched.

Northern Ireland had its own Parliament (Stormont), which, at the first opportunity, declined to be part of the Free State. It had extensive domestic competences, which have remained the basis of all subsequent devolution settlements there. The Ulster Unionist Party established a political hegemony, forming all governments for the duration of the Stormont regime. Control was assured by the abolition of the proportional representation provided for in the initial statute, combined with electoral gerrymandering, which, for example, allowed the Unionists continuous control of the majority Catholic city of Derry/ Londonderry ${ }^{1}$. Nationalists participated sporadically at Stormont and in UK elections in Northern Ireland, without much effect. There was widespread discrimination against the minority Catholic community. Successive UK Governments paid little attention to matters in the province.

During the 1960s, a civil rights movement, demanding the application of British standards of rights, gave rise to renewed nationalist agitation. Violence broke out, with organized paramilitaries mobilizing on both sides ('republicans' on the nationalist side and 'loyalists' on the unionist side). The British army was sent in to keep order and in 1972 the Stormont regime collapsed and the UK Government imposed direct rule. Political unionism splintered between the old Unionist Party, whose leadership had backed reform, and the intransigent Democratic Unionist Party of Ian Paisley. Nationalism was divided between the Social Democratic and Labour Party, committed to peaceful reform and Irish unity by consent, and Sinn Féin, linked to the paramilitary Irish Republican Army. Smaller parties formed around the loyalist paramilitary groups.

Efforts to resolve the conflict between 1973 and 1999 were focused on a consistent set of themes. First was power-sharing on consociational lines within Northern Ireland. Second was recognition of the right of Northern Ireland to unify with the Republic by consent of the people of Northern Ireland voting in a referendum; nationalists had previously claimed that the only relevant unit 
was the whole of Ireland. Third was the need for measures to open the border and reduce its practical significance. Fourth was recognition of the north-south dimension, meaning measures to bring the two parts of Ireland together, and of the east-west dimension, referring to measures to bring Northern Ireland closer to the other nations of the United Kingdom. The first effort, known as Sunningdale after the location of the conference at which it was agreed, sought to include the moderates in the shape of the SDLP and Unionist parties. The DUP was not invited as it had shown no inclination to compromise, while Sinn Féin had boycotted the preliminary elections. In the event, the Sunningdale agreement was brought down by a political strike of loyalist workers.

Efforts to restore devolution continued through the 1980s and 1990s. The Good Friday (or Belfast) Agreement of 1998 followed cease-fires by republican and loyalist paramilitaries and the election of the first Labour Government since 1979. It sought to encompass all parties, provided that they were committed to peaceful means and democratic participation. Sinn Féin was regarded as a legitimate partner because the IRA had officially abandoned violence, although unionists long disputed the point. The DUP did not accept the agreement but did participate in the new institutions conditionally. Eventually, through the St. Andrews Agreement (2006) it came on board fully. While the agreement, in contrast to Sunningdale, was intended to embrace the extremes as well as moderates, the conditions meant that Sinn Féin and parties representing loyalist paramilitaries could only come on board by becoming moderate. In effect, Sinn Féin and the DUP occupied the ground previously held by the SDLP and the Unionist Party, while participation allowed to overtake their moderate rivals in their respective communities so they, jointly, have led power-sharing governments since St Andrews.

The Republic of Ireland had a nominal claim to Northern Ireland although its 1937 constitution did provide for government in the 26 counties pending unification of the national territory. In practice, successive Irish governments did little to end partition. Indeed, it has been widely suggested that, from an early stage, they had little interest in absorbing what would have been a substantial and politically-mobilized unionist minority and preferred to pay lip-service to unification. UK Governments, for their part, took the view that Northern Ireland was a matter for domestic politics and jurisdiction. The Republic was, however, involved in negotiations for the Sunningdale Agreement. By the mid-1980s, British attitudes had evolved and in the Anglo-Irish Agreement of 1985 (https://cain.ulster.ac.uk/events/aia/aiadoc.htm), the UK had recognized the Government of Ireland as a partner in the venture, in spite of unionist objections, and established an Anglo-Irish Conference, predecessor to the British-Irish Intergovernmental Conference under the Good Friday Agreement. In the Downing Street Declaration of 1993 (https://cain.ulster.ac.uk/ events/peace/docs/dsd151293.htmit) the UK Government declared that it had no selfish strategic or economic interest in Northern Ireland. Both governments agreed that the future of Northern Ireland was for the people of Northern Ireland to decide by majority. At the same time, the United States began to play an active role. The European Union was less involved, except around measures to finance peace and development initiatives. The potential for Europe to reframe the issue was, however, identified by some as early as Sunningdale, which coincided with UK and Irish accession to the European Communities (Dorr 2017). Those involved in the negotiations have frequently noted how the regular contacts of Irish and UK ministers in EU meetings facilitated discussions and sharing of perspectives in a way that had not happened before.

While the two states retained competing claims to sovereignty over Northern Ireland and the UK, for legal purposes, saw it as an internal matter, the political reality is that neither side acted on these assumptions. Neither wanted to take full responsibility for what had become an intractable 
problem. Polls have long shown a large measure of indifference among the public in Great Britain about whether Northern Ireland should remain in the UK and some positive support for Irish unification, especially in Scotland (Keating 2021). After the Ulster Unionist Party broke their electoral and parliamentary alliance with the Conservatives in 1974, UK parties have nothing to gain in Northern Ireland and Northern Irish parties are influential only when they hold the balance of power (which they did 1976-79 and 2017-19). In the Republic of Ireland, there has been about two thirds support for unification in the long run but this falls off rapidly when respondents are faced with the cost. Northern Ireland has hardly been an issue in Irish electoral politics and even when Sinn Féin unexpectedly came first in the popular vote in 2020 this was all to do with domestic political issues.

\section{The Border Question}

When the border was established in 1922 its exact location was provisional, pending the report of a Commission. In the event, this came to nothing and it has continued to follow the old county boundaries. The border stretches for 499 kilometres and, at various points, curves north, south, east and west. Some 198 public roads cross it in addition to a few private roads and ferry services (Irish Department of Transport, Tourism and Sport 2018); some properties straddle it. Such a border is not easily patrolled and efforts to control it have come and gone over the years. Indeed, the meaning of the border is different from one sphere to another as government jurisdiction, security, the economy, sport, the organization of religion, education, the labour movement, infrastructure and public services are variously organised for southern and for Northern Ireland, for the United Kingdom, or across the islands (Moore 2019). In rugby, for example, there is a single Irish team along with national teams for England, Scotland and Wales while in football, Northern Ireland competes separately in international tournaments along with the Republic, England, Scotland and Wales. In the Olympic Games there are teams for the Republic of Ireland ${ }^{2}$ and the United Kingdom.

The movement of people has been governed by legally ill-defined set of arrangements collectively known as the Common Travel Area (CTA), many of which are derogations from restrictions that would otherwise apply between independent states (Connelly 2017). Under the Treaty establishing the Irish Free State, Irish people remained British subjects and thus allowed free travel on the same basis as Commonwealth citizens. When the Republic was declared in 1949, the UK decreed that, Irish citizens would no longer be citizens, they would still be treated as though they were still subjects and they remained free to travel, settle, work and even vote and hold elected office in the United Kingdom. When, from the 1960s, the United Kingdom progressively imposed immigration controls on Commonwealth citizens and codified its own citizenship regime, Irish citizens were simply exempted, either officially or in practice. The CTA has never been codified in legislation. The Republic, for its part, extended citizenship to the population of Northern Ireland on the same conditions as those in the south, entitled to Irish passports and to full citizenship rights if they moved to the south. Citizens of the Republic, however, did not enjoy reciprocal rights in Northern Ireland. The status of these provisions in UK and international law remained rather vague until the Good Friday Agreement, which clarified that citizens in Northern Ireland could have either or both citizenships.

The economic significance of the border dates from 1923, when the government of the Irish Free State erected customs posts. This aspect of the border was hardened in the 1930s, when the Irish 
Government of Eamon De Valera turned to protectionism and a mutually-damaging trade war broke out through the 1930s, linked to payments due from the Irish Government as compensation earlier British-financed land reforms. From the 1950s, Ireland began to open up its economy and a free trade agreement with Britain was signed in 1965, following de Gaulle's veto on UK accession to the European Economic Communities. Both countries were part of the European Free Trade Area (EFTA) and then joined the European Communities in 1973. With the arrival of the European Single Market in 1993, controls on trade in goods and services were removed altogether. Smuggling was long a feature of the border and continued where there were tax differences (as in agricultural diesel oil). There also remains an illegal trade drugs in people trafficking, often in the hands of paramilitary groups, which sometimes cooperate across sectarian lines (McDonald and Carroll 2020).

Some controls remained for sanitary and phytosanitary measures on agricultural products, applied between Ireland and Great Britain, the logic being that each island was a natural unit for such measures. Indeed, even DUP leader Ian Paisley remarked, during the 1005 Foot and Mouth Crisis in the UK that "Our people may be British but our cows are Irish". Pro-Brexit politicians were to make much of this as demonstrating that, as border controls exist and can be managed as a purely technical matter, there was little to fear from the end of the EU Single Market. In fact, the restrictions were sectoral and some of them also applied to the movement of livestock across the borders of England with Wales and Scotland.

The establishment of the two jurisdictions in northern and southern Ireland in 1922-3 was accompanied by violence and the border was securitized. Securitization was heightened during the regular campaigns by the successive incarnations of the Irish Republic Army, dedicated to the overthrow of both states. During the Second World War, border controls were imposed between both parts of Ireland and Great Britain, not removed until the early 1950s. During the Troubles between 1969 and 1999, free movement remained but security controls and military infrastructure increased on the border and only some twenty public road crossings remained open.

On the ground, the border remained a factor in everyday life. While larger political, security and economic forces governed its status, citizens approached it in multiple ways, negotiating their own position within it and relationships with people on either side (Hayward 2017; Todd 2018).

\subsection{The Good Friday Agreement}

The Good Friday (Belfast) Agreement of 1998 was negotiated with the UK and Irish Governments and the political parties within Northern Ireland after a long history of failed efforts (Coakley and Todd 2020) and ratified separately by both states. It was put to a referendum in both parts of Ireland and accepted massively in the Republic of Ireland and among nationalists in the north, and by a narrow majority of unionists. The Democratic Unionist Party opposed it until the St Andrews Agreement of 2006. This pattern of consistent nationalist and more reluctant unionist support has persisted, in spite of the fact that it secures Northern Ireland's position in the United Kingdom until such time as a majority in a referendum votes to unify the island, which represents a historic retreat on the traditional republican demand it is the island as a whole has the right of self-determination and that partition is illegitimate.

Indeed, the agreement leaves the United Kingdom in sovereign control of Northern Ireland. While the Republic of Ireland retains an aspiration to unity in the future, it changed its constitution to abandon the claim to jurisdiction there. Citizens of Northern Ireland were invited to define 
themselves as Irish, British or Northern Irish or any combination of the two and explicitly permitted to hold either British or Irish citizenship or both. The phrase, 'totality of relationships among the people of these islands' (first used in 1980) was deployed to soften hard sovereignty aspects and open up new territorial imaginations. Before then, it had been common in the United Kingdom to refer to the 'British Isles', which caused offence in Ireland and to 'Anglo-Irish' relations, which disturbed many Scots.

The agreement has two aspects, an internal and an external one. The internal aspect is founded on consociational principles. There is a Northern Ireland Assembly elected by single transferable vote. Members are invited (but not obliged) to designate themselves as nationalists or unionists. There is a power-sharing Northern Ireland Executive, which must include representatives of both communities. There are mechanisms requiring cross-community consent for certain measures. Specific programmes ensure equity in the police and public services. Powers have been devolved to the Assembly over time. At times when the Assembly and Executive are not functioning, responsibility reverts to the Secretary of State for Northern Ireland, working through the Northern Ireland Office, and to the Northern Ireland Civil Service.

The external aspect has two dimensions, north-south and east-west. A North-South Ministerial Council (NSMC) provides a vehicle for cooperation between the governments of the two parts of Ireland. It promotes cooperation on a range of policy matters. For east-west matters, there is a British-Irish Council. In order to promote the 'totality of relationships', it includes the two sovereign governments together with the Northern Ireland Executive, the Scottish and Welsh Governments, the Channel Islands and the Isle of Man. This also allows the Northern Ireland settlement to fit, at least in appearance, into an overall pattern of devolution within the United Kingdom. ${ }^{3}$ Finally, there is a British-Irish Intergovernmental Conference (BIIGC). This consists of the governments of the Republic of Ireland and the United Kingdom and was set up to oversee the settlement. When the Northern Ireland institutions were not working, the Council allowed the two governments to discuss policy matters, with the idea that it would become less important as devolution proceeded. Indeed, the threat that the alternative was Irish involvement in the government of Northern Ireland was, in the early years, used as an incentive to unionists to go into power-sharing. It has not been active in recent years as other mechanisms for cooperation are available.

The European Union played little part in the negotiation of the Good Friday Agreement although it does contribute funding to a Peace and Reconciliation Programme (PEACE). There are references in the GFA to cooperation in European programmes. More important is the fortuitous combination of the European Single Market programme and the peace process and cooperation between the two parts of Ireland. The opening of the economic border promoted cross-border trade. It also facilitated all-Ireland frameworks in issues such tourism (promoting Ireland as a single destination; energy (with a single market); public services; economic development; agriculture. With the issue of the political border put in abeyance, such cooperation could be depoliticized. At the border itself, community relations could be reconfigured and local forms of interaction and cooperation developed. The combination of desecuritization and the removal of economic controls allowed for the dismantling of the physical infrastructures at the border, which had an immense effect on perceptions of the border and local relationships. Joint membership of the EU on the part of the United Kingdom and Ireland also played an important role in relationships between the two states, as ministers met each other regularly at the Council of the EU and European Council, often sharing a common view of the future or Europe, where both were inclined to the market liberal approach. 
The free movement of people had long been established in the Common Travel Area so that the European provisions for free movement made no difference to the rights of UK and Irish citizens, although they did allow European citizens to move freely across the border.

Relations between the communities in Northern Ireland have remained tense and the powersharing institutions have broken down for two extended periods. Politically sensitive issues like dealing with the past, language and recognition remain open. While both communities were historically socially conservative, support for same-sex marriage and abortion rights have increased in the Republic and among Catholics while the DUP remains opposed. By contrast, the border was largely taken out of contention. Politicians in the Republic were obliged to pay lip-service to the long-term aim of unification but in practice only the republicans of Sinn Féin made an issue of it. When voters in Northern Ireland were offered a choice of constitutional options including Irish unification, direct rule from London and power-sharing within Northern Ireland, Catholics and those identifying as Irish ${ }^{4}$ moved away from their historic support for unification. By 2012, devolution was the first preference for a plurality of Catholics, the first time that unification had not been ahead (Keating 2021).

\section{The Politics of Brexit}

Support for the EU in the Republic of Ireland has consistently been high, with the exception of Sinn Féin and a section of the left concerned with sovereignty and the supposed neo-liberal bias of the EU. In the 1972 referendum on accession to the EEC, 83 per cent supported membership on a turnout of 71 per cent. Although there were two negative referendum votes on European treaties, these were rather easily reversed. After some years of membership, it was widely agreed that, rather than detracting from Ireland's sovereignty, Europe enhanced its status and autonomy as a small state. Opinion in Northern Ireland was more divided. The moderate nationalist Social Democratic and Labour Party (SDLP) was strongly in favour of the EEC, which it saw as contributing to relaxing the division of Ireland and consistent with its post-sovereigntist politics. Sinn Féin was opposed for the same reasons as in the Republic. Unionism was also divided. Moderate unionists in the Ulster Unionist Party (UUP) were themselves divided but were generally supportive. The DUP was strongly anti-European, on sovereignty grounds and because, for many, Europe was seen as Catholic. Moxon-Browne's (1983) survey of 1978 showed Catholics a little more favourable to Europe than Protestants (54 to 47 per cent). The main difference was between the moderate and hard-line parties. Sixty per cent of supporters of the SDLP were pro-Europe and 66 per cent of supporters of the non-aligned Alliance Party, against just 22 per cent of Democratic Unionist Party voters. Coakley (2020) shows that Northern Ireland opinion generally became more supportive of the EU from the 1980s but that DUP supporters remained least supportive and turned against Europe again in the 1990s. Sinn Féin supporters, in contrast, moved from 20 per cent to 60 per cent support in the same period. As the 2016 Brexit referendum approached, these positions largely held but with some qualifications (Murphy 2018). The SDLP and Alliance predictably came out for Remain. Sinn Féin, which had gradually been relaxing its hostility to Europe as, more generally, it took on the historic SDLP position on the constitution, also came out for Remain on the grounds that leaving the EU would bring back a hard border and 'repartition Ireland'. The DUP recommended Leave, although leaving the decision on how to vote to members. The UUP on balance favoured Remain, although many of its members and voters favoured Leave. 
In the referendum of 2016, the UK as a whole voted 52-48 per cent to leave the EU; the figures for England and for Wales were similar. Scotland voted 62-38 to remain. Northern Ireland voted to remain by 56-44 per cent but with a large difference between the communities.

Table 1. Brexit Vote, Northern Ireland, Percentage

\begin{tabular}{llll}
\hline & Nationalist & Unionist & Neither \\
\hline Remain & 88 & 34 & 70 \\
Leave & 12 & 66 & 30 \\
Total & 100 & 100 & 100
\end{tabular}

Brexit Vote, Northern Ireland, Percentage

Source: Garry (2017b)

SDLP voters supported Remain by 95 per cent, while Sinn Féin voters were only slightly behind at 86 per cent. By contrast 70 per cent of DUP voters went for Leave as did 54 per cent of UUP voters (Coakley, 2020).

Sinn Féin's immediate response was to call for a border poll as allowed under the Good Friday Agreement but they were not supported by moderate nationalists or the main Irish parties as the difficulties were too great and they were committed to the GFA. In the following years, however, support for reunification did increase within the nationalist community and by 2018 there was again a plurality among Catholics for unification, overtaking the status quo of devolution with power sharing (Northern Ireland Life and Times Survey). Forty nine per cent of them would vote for unification in a referendum, against 25 per cent who would vote to remain with the UK, but with 26 per cent undecided. Brexit had clearly driven a new wedge between the two communities.

\subsection{Consequences of Brexit}

With the Ireland inside the EU and the UK outside, there were obvious consequences for the border; it was also a highly salient political issue (Hayward 2018).. Prime Minister Theresa May's (2017) early declaration (in the Lancaster House speech of January 2017) that the UK would leave the Customs Union and the Single Market suggested that there would be a hard border, not the open one that had existed hitherto. Either a customs and regulatory border would need to be reimposed between the two parts of Ireland, or, to keep Ireland together, one would have to be erected within the UK between Northern Ireland and Great Britain. ${ }^{5}$ This logic is inescapable, however much some of the protagonists tried to deny it. Exactly what form these borders would take, however, would depend on the future relationship between the UK and the EU. If there were a close arrangement or association agreement, the barriers would be lower. If there were no deal, they would be higher.

All involved agreed that nothing should be done to damage the Good Friday Agreement, but this could be interpreted in a broad or a narrow way. There is rather little in the GFA about Europe, apart from some generalities about cooperation and funding; there is no requirement that both states remain in the EU. On the other hand, the EU and Single Market provide the context and conditions for opening the border and largely taking it out of political contention. The development of the Agreement over time (what we might call, to borrow European terminology, the acquis) owes a great deal to the opportunities provided by Europe, including all-Ireland management of energy, 
tourism and other matters. The removal of the physical frontier has immense symbolic importance and matters for the everyday life of people on both sides. The open border to the south provided an underpinning for the territorial imagination of nationalists, giving an all-Ireland perspective. An open border with Great Britain did the same for unionism. Borrowing terminology from the EU, we might argue that there is a border acquis that has broadened and deepened over two decades and which would be undermined by Brexit.

\subsubsection{The Actors}

The position of the UK Government was that Brexit, including withdrawal from the Single Market, could be achieved without harming the GFA. Yet, as negotiations progressed, especially after the fall of Theresa May, it insisted on an ever harder Brexit on the grounds that anything less would compromise its sovereignty. To square the circle, they adopted a narrow interpretation of the GFA, focusing on the letter rather than its subsequent development. They also took a restricted view of the border, focusing on the physical structures rather than the functional and symbolic elements. A repeated slogan was that there would be 'no return to the borders of the past'. They consequently argued that it would be acceptable to move physical checks a few kilometres away from the border and put great faith in technology to deal with monitoring and inspection. These, however, are all ways of managing the border rather than eliminating it. In the early stages, they also sought bilateral negotiations with Ireland, only to be told that they had to negotiate with the EU (although some technical work was done bilaterally). In its negotiating on the Irish border question, the UK was little constrained but public opinion in Great Britain, which has long been largely indifferent as to whether Northern Ireland remains in the UK or joins the Republic (Keating 2021). The British political parties do not field candidates in Northern Ireland. Indeed polls taken after the vote and during the Brexit negotiations showed that a majority of Leave voters in England ${ }^{6}$ regarded the departure of Northern Ireland (and, by a smaller majority), Scotland as an acceptable price to pay for achieving Brexit (Future of England Survey 2019; Ashcroft 2019).

Ireland is the EU Member State most affected by Brexit generally. While dependence on the UK market has fallen drastically since 1973, it still accounts for 11 per cent of Irish exports (of which one per cent is to Northern Ireland). The figures for agricultural exports are higher. Equally important, over 28 per cent of containerised Irish goods exports into Europe went via the 'land bridge' through the Wales and England (Breen et al, 2018). One response to Brexit has been to reduce this dependency by establishing direct links to the Continent but the through-traffic remains considerable. Ireland's other great concern was Northern Ireland and the border. Its position was that keeping the border open meant Northern Ireland adhering very closely to the Single Market regime. In the immediate aftermath of the Brexit vote, there was a widespread view that Ireland could be the weaker party in the negotiations and might have to cleave to the UK but this rapidly dissipated as Ireland aligned itself as part of the European team and a loyal player. This paid off as the Irish border became a key breaking point in the negotiations.

The Northern Ireland parties were, as usual, divided. The nationalists were adamant that the Good Friday Agreement be upheld in its broadest sense and there be no border in Ireland, even it this meant a border in the Irish Sea between Ireland and Great Britain. Sinn Féin, by now the dominant party on the nationalist side, does not take its seats in the UK Parliament, so weakening its position. The DUP, the largest unionist party, was pro-Brexit despite the threat this posed to the 
GFA and thus to its own position as leader of the devolved government. It regarded a border of any sort in the Irish Sea as completely unacceptable. In January 2017, the power-sharing Executive collapsed for reasons going beyond Brexit although Brexit had added to the tensions. It was not reconstituted until January 2020, meaning that an authoritative Northern Ireland voice was lacking for much of the negotiating period. At the snap General Election of 2017, however, the Conservative Government of Theresa May unexpectedly lost its majority. It immediately negotiated a confidence and supply agreement with the DUP, greatly increasing the latter's leverage and putting into doubts it's the UKs's own credentials as an honest broker between the two sides in Northern Ireland. There was a brief rediscovery of the Conservative Party's credentials as a unionist party (its official name remains the Conservative and Unionist Party) but this did not last.

The main concern of the European Union in the negotiations was to ensure that a departing Member State could not retain the full advantages of market access. It also stressed the integrity of the single market, so that it was unwilling to countenance a potentially leaky border in Ireland (European Commission 2017). The EU ruled out bilateral negotiations on the part of Member States in order to retain unity but, in their negotiating guidelines of April 2017 adopted a resolution of the Irish border question as one of the three conditions that needed to be fulfilled before substantive negotiations could start on the withdrawal agreement with the UK. That, in turn, had to precede negotiations on the future relationship. While the EU avoided directly intervening in the question of Irish unification, as this was a state matter, the European Council did indicate that a united Ireland would automatically be a Member State, following the German precedent (European Parliament 2017).

\subsubsection{Negotiating Brexit}

The Irish border issue hardly featured in the referendum campaign in Great Britain and many people appear to have been surprised that it existed and was given such attention in the aftermath. Some Brexiters (such as veteran Eurosceptic John Redwood, 2017) sought to dismiss the issue by declaring that, if a border were erected, it would be the fault of the Irish and the Europeans; they had no intention of doing it. Coming from people campaigning on the slogan of 'take back control of our money, our laws and our borders' this is a little difficult to fathom. The Europeans, however, made it one of their three starting conditions, along with citizens' rights and the financial settlement. Only after negotiations had started with the triggering of Article 50 in March 2017 did a serious engagement begin, at two levels. There were technical explorations by the UK and Irish officials of the ways in which Brexit, devolution and the GFA overlapped, covering some 142 items. Yet, there was a large difference in understandings of the principles involved (Connolly 2018). For the UK, it was a matter of dealing with the technicalities and precise points. For the Irish, keeping the border open meant Northern Ireland effectively remaining in the Single Market and Customs Union. Arcane discussions focused on the difference between 'regulatory divergence' and 'lack of regulatory alignment'.

Agreement appeared to have been reached in December 2017 on a formula with three elements. First was a hope that the border would be taken care of in a future trade deal. Second was a wish that a technical solution would be found. Third was a differentiated arrangement for Northern Ireland, keeping it within the regulatory and customs alignment to the degree necessary to safeguard the GFA, until such time as a better arrangement could be found. This became the famous Irish 
Backstop. In practice, it was difficult to see how a future trade agreement could work unless it incorporated the third element. As for the second, the requisite technology did not exist and in any case a virtual border is still a border. This left the differentiated Brexit and the backstop. As news of the draff deal filtered out of Brussels, the DUP reacted furiously, threatening to use its confidence and supply arrangement with the Conservatives to veto it. The Prime Minister was then forced to downplay the differentiation. The resulting Joint Report (UK Government 2017c) provided that the whole of the UK would be in a single customs area with the EU (the Customs Union in all but name). Northern Ireland alone would remain in regulatory alignment with the EU for limited, but unspecified purposes. There were vague assurances that there would not be a border in the Irish Sea. On this, far-from-clear basis, the DUP backed off and the EU accepted that negotiations could proceed. In February 2018, the European Commission (2017b) published its own interpretation of the Joint Report, which made it clear that Northern Ireland would effectively remain in the Single Market and Customs Union. The Irish Government had a similarly broad interpretation of the agreement. The UK Government disagreed.

Prime Minister Theresa May's Cabinet was deeply divided over Brexit, as was the Conservative parliamentary party. The Chequers Plan of July 2018 sought to get consent from the Cabinet as a basis for negotiating with the EU. May proposed building on the provision for the whole UK to stay in a common customs arrangement to make it part of a permanent deal and also wanted a 'common rule book' on regulation, with some provision for the UK to diverge and face the consequences. Several ministers, including Boris Johnson resigned in protest, mainly because of the close relation it implied with the EU but they also made common cause with the DUP in opposing differentiation for Northern Ireland and the Irish Sea Border. In the event, the Chequers Plan did not find favour with the EU either.

With the hardliners out of government the first withdrawal agreement between the UK and the EU was reached in November 2018. It did not provide for a customs union or common rule book but the accompanying Political Declaration envisaged:

comprehensive arrangements that will create a free trade area, combining deep regulatory and customs cooperation, underpinned by provisions ensuring a level playing field for open and fair competition (UK Government 2018a).

The agreement also included a Northern Ireland Protocol, which provided for 'a common regulatory area comprising the Union and the United Kingdom in respect of Northern Ireland... The common regulatory area shall constitute an area without internal borders in which the free movement of goods is ensured and North-South cooperation protected. ... Customs duties on imports and exports and any charges having equivalent effect shall be prohibited between the Union and the United Kingdom in respect of Northern Ireland' UK Government 2018c)

For the UK Government (2018b), this was still a backstop, as it clung to the hope that the future trade agreement and technology would resolve the problem. In the meantime, it would address:

the unique circumstances in Northern Ireland, including the continuation of the Common Travel Area arrangements, the ongoing protection of rights of individuals in Northern Ireland, and guarantees that, even in the unlikely event that our future relationship with the EU is not in place by the end of the implementation period, there will be no hard border between Northern Ireland and Ireland or a splitting of the UK customs territory.

Once again, this left a wide margin for interpretation. Logically, for the future trade agreement to keep the Irish border open to the same extent as the Protocol did, it would have to include the 
substance of the Protocol but the UK Government refused to accept this conclusion. Nor were the assurances enough to satisfy either the DUP or the nationalists in Northern Ireland. In the event, Theresa May failed to get the deal through Parliament, leading to her resignation in June 2019. Her successor, Boris Johnson, a leading Brexiter, promised to scrap the Northern Ireland Protocol as part of a renegotiated deal. At the same time, his government moved to a harder interpretation of Brexit, away from customs and regulatory alignment. This made the claim that the future trade agreement would solve the Irish border question even less plausible.

The deal concluded by Johnson in January 2020 ostensibly removed the backstop but only by making it permanent (a frontstop as critics called it). Northern Ireland was to remain within regulatory alignment with the EU and effectively in the customs union, while also remaining within the UK's customs territory. The DUP, at whose conference in 2018 Johnson had denounced the backstop and any differentiated treatment for Northern Ireland, was abandoned and a border was introduced in the Irish Sea.

The Protocol commits the UK to facilitate the work of the institutions and bodies pursuant to the Good Friday Agreement, notably in relation to Human Rights.

It secures the Common Travel Area, while also stressing Ireland's commitments under EU free movement provisions. Northern Ireland is defined to be part of the customs territory of the United Kingdom, including for the purpose of free trade agreements with third countries. At the same time, Northern Ireland has customs-free trade with the EU. As there is, unlike the previous draft agreement (Theresa May's deal) there is no common customs area. This means that there are customs checks in the Irish Sea. No customs duties are payable on good imported to Northern Ireland from other parts of the UK, unless it is at risk of being sent on to the EU, in which case any applicable duties must be paid. Northern Ireland is also subject to EU regulations in a wide range of Single Market areas and state aid provisions. This, also, requires checks on goods moving there from Great Britain. Northern Ireland remains in the UK VAT rules but subject to EU VAT regulations. These rules are enforced by the European Commission and the Court of Justice of the EU. It is clear, then, that the red lines on which the UK Government insisted from the beginning to do not apply to Northern Ireland.

One concession was made to the DUP, that the arrangement could be reviewed after four years and terminated by vote of the Northern Ireland Assembly. If the decision is taken by simple majority, it can be reviewed every four years. If it gains a qualified majority of 60 per cent and at least 40 per cent in among both unionist and nationalist members, then it cannot be revisited for another eight years. If the protocol is voted down, the sides have to review the situation. In practice, as the DUP is the only party objecting to the protocol, it is highly unlikely that it would be repealed.

Like the overall withdrawal agreement, there is much to be negotiated in practice and in detail and interpretations differ. Boris Johnson initially declared that there would be no checks at the border (ITV, 2019); EU negotiator Michel Barnier insisted that there would (Guardian, 27-01-2020). Johnson later admitted that there would (Colston, 2020). Experience proved that Barnier was correct.

\section{Conclusion}

Brexit was always an ill-defined project, taking harder or softer forms. Theresa May's Lancaster House speech at the beginning of the process seemed to presage a hard Brexit and thus a hard 
Irish border. Later, the position appeared to soften as propose a wide partnership with the EU (UK Government 2017a). The final deal, followed by the Trade and Cooperation Agreement, represented a hardening of the position as a result of the UK's insistence on an absolute notion of sovereignty. This collided with the EU and Irish insistence on keeping the border open. Something had to give, and it was the border in the Irish Sea.

Brexit has destabilized the delicate constitutional settlement in Northern Ireland. Internally, it has increased the gulf between nationalists and unionists. Externally, it has brought back to border issue as a matter of contention and put Irish reunification back on the political agenda. The DUP, which had supported Brexit but played down the impact on the Irish border and refused to accept an Irish Sea border, lost out. Nationalists scored a victory by keeping open the Irish land border, even at the expense of imposing a regulatory border between Northern Ireland and Great Britain. Of course, there is still a juridical border between the two parts of Ireland but it is less intrusive in practice than the new border within the United Kingdom. The early indications as the new arrangements came into effect in January 2021 were that the Irish Sea border was not a mere matter of invisible formalities, any more than the new border with the EU was (Campbell 2021). Northern Ireland citizens were told that they would have the best of both worlds in the form of free access to both EU and UK markets ${ }^{7}$ but there were upsets in the supply chains. Nationalists in Northern Ireland were upset about Brexit happening in defiance of the majority Remain vote there and the cross-community Alliance Party remain strongly pro-European. The constitutional settlement in the United Kingdom provides that the Westminster Parliament will not 'normally' legislate in devolved matters or change the devolution settlement without the consent of the relevant devolved legislature - this is the Sewel Convention. One of the casualties of the legal conflicts over Brexit had been the Sewel Convention itself, which the UK Supreme Court (2017) had dismissed as merely a 'political' convention. It was therefore of no effect that the Northern Ireland Assembly, in a rare display of cross-community consensus, unanimously refused to give consent to the Withdrawal Agreement Bill (now Act). The Scottish and Welsh Parliaments also declined to give consent to it.

For the United Kingdom, the outcome breaks the pledge that there would be a 'Red, White and Blue' Brexit. As Theresa May repeatedly said 'We entered the EEC, as it was, as a whole UK, we're leaving the EU as a whole United Kingdom.' (Scotsman, 29-11-2018 https://www.scotsman.com/news/politics/theresa-may-tells-nicola-sturgeon-stopexploiting-brexit-scottish-independence-200221). Yet, while the trappings of sovereignty and statehood were preserved, they have been emptied of substance. An internal customs and regulatory border has been erected within the UK, against the repeated denials of successive prime ministers. In 2020, the UK Government introduced the UK Internal Market Act (BEIS 2020a, b), providing for non-discrimination and mutual recognition of goods and services across the United Kingdom after Brexit, in the face of strong opposition from the Scottish and Welsh Parliaments, which felt that their regulatory autonomy would be undermined. A provision was included to the effect that, in Northern Ireland, this would be subject to the international obligations of the United Kingdom, a reference to the Protocol, thus further distancing Northern Ireland from the rest of the UK.

The domestic political repercussions within Great Britain to hiving off Northern Ireland have been slight. Some Conservative voices complained that Northern Ireland has been 'annexed' by the EU but few voters care. The UK Government, instead, has drawn the line at Scotland, refusing a differentiated Brexit as proposed by the Scottish Government (2016), which would have kept 
Scotland in the Single Market. It has also stood firm against another referendum in Scotland, allowing Scotland to leave the UK and rejoin the EU. Northern Ireland thus remains dispensable for the UK's vision of itself as a sovereign state. Suggestions that both Scotland and Northern Ireland could remain in the EU in some form while England and Wales left (O'Leary 2016) were never entertained in London and so did not enter the negotiation.

The Irish Government was largely successful in its aims, retaining an open border and cementing its position as a loyal European. Once again, it demonstrated that, by working as part of the EU, it could gain considerably more leverage than though bilateral negotiation with the United Kingdom. This echoes the way it made progress in the 1990s by externalizing the Northern Ireland question by bringing on board the United States Presidency and Congress.

The EU achieved its aim of protecting the border of the Internal Market while supporting the demands of the Irish Government. Indeed, it obliged a departing Member State to erect an economic border within its own territory in spite of the frequent protestations of the UK and repeated pledges of UK leaders. Boris Johnson's deal in regard to the Irish border effectively conceded the Irish and European case against which he had campaigned and was the most antagonistic to the UK unionist position of all the various proposals that had been canvassed so far. He achieved this because Northern Ireland was not an issue for the British public or even, when it came to it, the Conservative and Unionist Party.

The settlement remains fragile, often ill-understood on both sides and vulnerable to events. Both sides undermined it in the early stages. The UK Government introduced a provision in its UK Internal Market Bill in late 2020. allowing it to disapply any controls on movements between Northern Ireland and Great Britain, while conceding that this violated the withdrawal agreement and international law, as the Secretary of State for Northern Ireland put it, in a very specific and limited way.' This was clearly not going to help the UK's negotiations for a trade agreement with the EU (although some ministers seemed to think it would enhance their negotiating position) and, after and the relevant bill was amended by the House of Lords, the Government dropped the provision. In January 2020, the EU Commission announced that it would over-ride part of the Protocol in order the control the movement of Covid vaccine out of the EU via Northern Ireland. They, too, had to back down after an outcry united the Irish and British Governments and all the parties in Northern Ireland.

It is difficult to generalize from the case, because the circumstances of Northern Ireland are unique. The EU has hitherto allowed Member States selectively to opt out of provisions in treaties and non-Member States selectively to opt in. It has allowed regions of Member States to opt out entirely (Greenland, Faroes) or partly (Canaries, Azores). This is the only case when a region of a non-Member state has partially opted in. Not even Northern Cyprus' exclusion is comparable, since that is a non-recognised territory. The case, rather, shows how the EU has sought to maintain the borders of the Single Market and tightly circumscribe the conditions under which a non-state territory can be partially within the EU's economic space.

\section{Acknowledgments}

The research for this paper was supported by European Commission research grant 822304, for the project Integrating Diversity in the European Union. 


\section{References}

ASHCROFT, Lord (2019) England and the Union https://lordashcroftpolls.com/2019/10/england-and-the -union/

BREEN, Ben, BREWSTER, Paul, O’ DRISCOLL, Ciarán, TSAKIRIDIS, Andreas (2018) The Implications of Brexit on the Use of the Landbridge, Dublin: Irish Maritime Development Office.

COAKLEY, John and Jennifer TODD (2020) Negotiating a Settlement in Northern Ireland, 1969-2019 (Oxford: Oxford University Press).

CONNELLY, Tony (2017) Brexit \& Ireland. The Dangers, the Opportunities, and the Inside Story of the Irish Response, Dublin: Penguin Ireland.

COAKLEY, John (2020) "Choosing between unions? Unionist opinion and the challenge of Brexit", Irish Political Studies, 35:3, 356-377.

COLSTON, Thomas (2020) 'Boris Johnson promised frictionless trade after Brexit but now his government admits new border checks are 'inevitable', Business Insider, 11-02-20, https://www.businessinsider.com/boris-johnson-michael-gove-admits-brexitborder-checks-are-inevitable-2020-2?r=US\&IR=T

CONNELLY, Tony (2018) Brexit: A brief history of the backstop, RTE, 20 Oct 2018, https://www.rte.ie/news/ brexit/2018/1019/1005373-backstop-tony-connelly;l

DEPARTMENT FOR EXITING THE EUROPEAN UNION (2018), Withdrawal Agreement and Political Declaration on the future relationship between the UK and the EU, https://www.gov.uk/government/ publications/withdrawal-agreement-and-political-declaration

BEIS (Department of Business, Energy and Industrial Strategy) (2020a), UK Internal Market, CP 278, London: UK Government.

BEIS (Department of Business, Energy and Industrial Strategy) (2020b), Internal Market Bill, 2020: Policy Statements, https://www.gov.uk/government/publications/uk-internal-market-bill-2020-policy-sta tements

CAMPBELL, John (2021) Brexit: Can Irish Sea border 'teething problems' be solved? BBC https://www.bbc.c o.uk/news/uk-northern-ireland-55772522

DORR, Noel (2017) The Search for Peace in Northern Ireland. Sunningdale, Dublin: Royal Irish Academy

EUROPEAN COMMISSION (2017a) Guiding principles for the Dialogue on Ireland/Northern Ireland, TF50 (2017); Brussels: European Commission.

EUROPEAN COMMISSION (2017b) Press Release. European Commission recommends tgo the European Council (Article 50) to find that decisive progress has been made in Brexit negotiations https://ec.eur opa.eu/commission/presscorner/detail/en/IP_18_6424

EUROPEAN COMMISSION (2020) Draft Text of the Agreement on the New Partnership with the United Kingdom, UKTF (2020) https://ec.europa.eu/info/sites/info/files/200318-draft-agreement-gen.pdf

EUROPEAN PARLIAMENT (2017) At a Glance. Post-European Council Briefing, https://www.europarl.euro pa.eu/RegData/etudes/ATAG/2017/603226/EPRS_ATA(2017)603226_EN.pdf.

FUTURE OF ENGLAND SURVEY (2019) https://www.cardiff.ac.uk/_data/assets/pdf_file/0010/1708624/ Copy-of-Wales-16-Oct-AH.pdf

GARRY, John (2017) The EU referendum Vote in Northern Ireland: Implications for our understanding of citizens' political views and behaviour https://www.qub.ac.uk/brexit/Brexitfilestore/Filetoupload.72 8121.en.pdf 
GARRY, John (2017b) The EU referendum Vote in Northern Ireland: Implications for our understanding of citizens' political views and behaviour https://www.qub.ac.uk/brexit/Brexitfilestore/Filetoupload.72 8121.en.pdf

HAYWARD, Katy (2017) Bordering on Brexit. Views from Local Communities in the Central Border Region or Ireland/Northern Ireland, Belfast: Irish Central Border Area, Queen's University.

HAYWARD, Katy (2018) “The pivotal position of the Irish border in the UK's withdrawal from the European Union", Space and Polity, 22, 238-54.

IRISH DEPARTMENT OF TRANSPORT, Tourism and Sport (2018), Border Crossings Report 2018 http://dtt as.old.gov.ie/roads/publications/english/border-crossings-report-2018

JOHNSON, Boris (2020) UK / EU relations: Written statement HCWS86, https://www.parliament.uk/business/publications/written-questions-answers-statement s/written-statement/Commons/2020-02-03/HCWS86/

KEATING, Michael (2021) State and Nation in the United Kingdom: The Fractured Union, Oxford: Oxford University Press.

MAY, Theresa (2017) Plan for Britain. The Prime Minister's speech on Brexit, London: Prime Minister's Office, https://www.gov.uk/government/speeches/the-governments-negotiating-objectives-for-exiti ng-the-eu-pm-speech

MCDONALD, Henry and Rory CARROLL (2020) “How IRA and the Troubles 'industrialised' people smuggling in Ireland", Guardian, 21, 12-20.

MOORE, Cormac (2019) Birth of the Border. The Impact of Partition in Ireland, Newbridge: Merrion.

MOXON-BROWNE, Edward (1983) Nation, Class and Creed in Northern Ireland, Aldershot: Gower.

MURPHY, Mary (2018) Europe and Northern Ireland's Future. Negotiating Brexit's Unique Case, Newcastle: Agenda.

O'LEARY, Brendan (2016) The Dalriata Document. Towards a Multinational Compromise that Respects Diversity in the United Kingdom, Belfast: Queen's University. https://www.qub.ac.uk/Research/GRI/ mitchell-institute/FileStore/Filetoupload.756968.en.pdf

REDWOOD, John (2017) The EU now threatens the Republic of Ireland with a hard border, https://johnred woodsdiary.com/2017/11/10/the-eu-now-threatens-the-republic-of-ireland-with-a-hard-border/

REDWOOD, John (2017) The EU now threatens the Republic of Ireland with a hard border, https://johnred woodsdiary.com/2017/11/10/the-eu-now-threatens-the-republic-of-ireland-with-a-hard-border/

SCOTTISH GOVERNMENT (2016) Scotland's Place in Europe, Edinburgh: Scottish Government.

TODD, Jennifer (2018) Identity Change after Conflict. Ethnicity, Boundaries and Belonging in the Two Irelands, Basingstoke: Palgrave.

UK GOVERNMENT (2017a) The United Kingdom's exit from and new partnership with the European Union, London: UK Government.

UK GOVERNMENT (2017b) Joint report on progress during phase 1 of negotiations under Article 50 TEU on the UK's orderly withdrawal from the EU, https://www.gov.uk/government/publications/joint-report-on-progress-during-phase-1-of-neg otiations-under-article-50-teu-on-the-uks-orderly-withdrawal-from-the-eu

UK GOVERNMENT (2018a) Political Declaration setting out the future framework, https://assets.publishing.service.gov.uk/government/uploads/system/uploads/attachm ent_data/file/759021/25_November_Political_Declaration_setting_out_the_framework_for_the_futur e_relationship_between_the_European_Union_and_the_United_Kingdom_.pdf

UK GOVERNMENT (2018b) Explainer for the agreement on the withdrawal of the United Kingdom from the European Union https://assets.publishing.service.gov.uk/government/uploads/system/uploads/atta 
chment_data/file/759020/14_November_Explainer_for_the_agreement_on_the_withdrawal_of_the_U nited_Kingdom_of_Great_Britain_and_Northern_Ireland_from_the_European_Union.pdf

UK GOVERNMENT (2018c) Agreement on the withdrawal of the United Kingdom of Great Britain and Northern Ireland from the European Union and the European Atomic Energy Community, as endorsed by leaders at a special meeting of the European Council on 25 November 2018 https://assets.publishing .service.gov.uk/government/uploads/system/uploads/attachment_data/file/759019/25_November _Agreement_on_the_withdrawal_of_the_United_Kingdom_of_Great_Britain_and_Northern_Ireland_fro m_the_European_Union_and_the_European_Atomic_Energy_Community.pdf

UK SUPREME COURT (2017) Judgment R (on the application of Miller and another) (Respondents) vs. Secretary of State for Exiting the European Union (Appellant), USC 5 (2017)

Notes

Derry to nationalists and Londonderry to unionists.

2 The name of the state has historically been contentious. Following Good Friday Agreement, the agreed name is now 'Ireland' but 'Republic of Ireland' will be used where necessary to distinguish it from Northern Ireland.

3 Although the Isle of Man and Channel Islands are not actually devolved territories but Crown Dependencies.

$4 \quad$ These are not quite the same.

5 That is the term for England, Scotland and Wales together.

6 Support for Brexit is strongly related to identifying as English rather than British.

7 Which, of course they had previously enjoyed within the EU. 